\title{
The effect of financial ratios, firm size, and cash flow from operating activities in the interim report to the stock return
}

\author{
Dwi Martani, Mulyono, Rahfiani Khairurizka \\ (Accounting Department, Faculty of Economics, University of Indonesia, Depok 16424, Indonesia)
}

\begin{abstract}
The objective of this study is to examine the value relevance of accounting information in explaining stock return. The study uses profitability, liquidity, leverage, market ratio, size and cash flow as proxies of accounting information. Cumulative abnormal return and market adjusted return are used as stock return variables. The samples of the study are listed companies in manufacturing industries that actively trading between 2003-2006 in Indonesia Stock Market. The study finds that profitability, turnover and market ratio has significant impact to the stock return. The result consistent with previous studies Hobart (2006), Utama and Santoso (1998) and Restraningsih (2007).
\end{abstract}

Key words: financial ratio; stock return; Indonesia Stock Market

\section{Introduction}

Accounting information from financial reports can describe firm's condition. The financial reports are affected by two factors, firms' activities and accounting system adopted by the firms (Palepu, Healy \& Bernard, 2004). There are many researches in value of financial reports information (both annual and interim reports). Some researches study accounting information in predicting firms' future financial performance, such as earnings and growth (Lev Trigrajan, 1993), while other researches measure the effect of accounting information on share price (Abarbanell \& Bushee, 1998).

This research reinvestigates the relationship between financial reports information and return on share by using five categories of commonly used financial ratios (Ross, Westerfield \& Jordan, 2006) including profitability, long term solvency/leverage, short term solvency/liquidity, asset utilization/turnover, and market value. In addition, it uses two additional variables from previous research; Size which is derived from firm's total assets (Johnson \& Soenen, 2003; Hobarth, 2006), and cashflow from operation (Daniati \& Suhairi, 2006; Susanto \& Ekawati, 2006; Meythi, 2006).

The reminder of this paper is organized as follows. The next section contains literature review and followed by methodology. The third section discusses research result. Conclusions and suggestions for future research are discussed in the final section.

\section{Previous studies}

Dwi Martani, lecturer, Ph.D., Accounting Department, Faculty of Economics, University of Indonesia; research fields: financial accounting, public sector accounting, governance, taxation.

Mulyono, graduate student, Accounting Department, Faculty of Economics, University of Indonesia; research field: financial accounting.

Rahfiani Khairurizka, lecturer, Master, Accounting Department, Faculty of Economics, University of Indonesia; research fields: financial accounting, information system. 
Financial ratio analysis can help investors in making investment decision and predicting firm's future performance. It can also give early warning about the slowdown of firm's financial condition (Ohlson, 1980).

Research in finance shows that firm's characteristics (such as growth, company size, efficiency) can predict the future stock price. Johnson and Soenen (2003) analyzed 478 firms in USA during 1982-1998 and concluded that big sized and profitable firms with high level advertising expenditure have better performance in terms of those three measurements.

Hobarth (2006) studied the correlation between financial indicators and firm's performance of listed firms in USA for 19 years period by using 17 financial indicators and three variables to measure firm's performance, namely market performance ( $\triangle$ stock market value), cash flow performance (dividend per share), and profitability (ROI). The result shows that firms with low book to market ratio, efficient working capital management, low liquidity, more equity and less liabilities, and high retained earnings have high profitability based on ROI. Firms with unqualified opinion from auditor, more liabilities and less equity, low total assets and retained earnings have better cash flow performance (measured by cash dividend). Furthermore, firms with low book to market ratio, efficient working capital management, more equity and less liabilities, low total assets, and high EBIT margin have better market performance (measured by changes in stock price).

Research about accounting information for predicting return on shares is also conducted in Indonesia. Daniati and Suhairi (2006) showed that cash flow from investing activities, gross profit, and company size significantly affect expected return on shares. On the other hand, cash flow from operating activities does not affect expected return significantly. Meythi (2006) researched 100 manufacturing firms in BEJ during 1999-2002 and concluded that, with profit persistence as intervening variable, cash flow from operating activities does not affect stock price.

In USA, Lev and Thiagarajan (1993) performed a research on correlation between 12 fundamental variables and firm's abnormal return for period 1974-1988, by using changes in inventory, accounts receivable, capital expenditure, R \& D, gross margin, sales \& administrative expense, provision for doubtful receivable, effective tax, order backlog, labor force, LIFO earnings, and audit qualification as independent variables. The result showed that changes in inventory, receivable, capital expenditure, gross margin, sales $\&$ administrative expense, and order backlog significantly affect return, with $\alpha=5 \%$. They also observed that the correlation between return and fundamental variables will be stronger when considering macroeconomics variables such as inflation rate and GNP growth.

The research is continued by Abarbanell and Bushee (1998). They observed whether the application of fundamental analysis can result in abnormal return using data from 9,764 companies during 1974-1988. Fundamental analysis in this research was performed by observing changes in inventory, accounts receivable, gross margins, selling expenses, capital expenditures, effective tax rates, inventory methods, audit qualifications, and labor force sales productivity. The result shows that changes in inventory, gross margin, and selling and administrative expenses provide information about firm's future return which is associated with earnings announcement in the future. Among all variables in this research, changes in inventory, capital expenditure, effective tax rates are strong indicators in predicting firm's future earnings. Most of the abnormal returns happen during the period before and after earnings announcement.

Different results came from research performed by Warfrield and Wild (1992) which showed empirical evidence of negative correlation between explanatory power of firm's earnings and the length of reporting period. Using quarterly report from 24,150 firms during period 1983-1986 as samples, they concluded that the explanatory power of earnings in explaining return in a quarterly report was only $25 \%$ of semiannual report, and 
less than $10 \%$ of annual report. Adjusted- $\mathrm{R}^{2}$ in quarterly earnings is less than $1 \%$, but more than $39 \%$ in 4 -years earnings.

Based on a study by Lev, Thiagarajan (1993), Anggraini, Setiawati and Desembriarto (2004) tried to learn the effect of fundamental variables on abnormal return during crisis and non-crisis period. The research period is 1995-2002, where 1998 is considered as crisis period. This paper uses seven fundamental variables: inventory, accounts receivable, gross profit, marketing and administrative expense, allowance for doubtful account relative to sales, effective tax rate, and audit qualifications. During crisis period, only gross profit affects abnormal return significantly, while in non-crisis period inventory, financial reports, and audit qualifications have significant influence on abnormal return. The important thing is the low adjusted- $\mathrm{R}^{2}$ which is only $0.5 \%$ (for crisis period) and $0.8 \%$ (for non-crisis period). This indicates the low ability of fundamental signals to explain the return variability in capital market.

Manao and Nur (2001) observed the relation between financial ratio and stock returns during economic crisis in Indonesia by adding firm size as variable. Using 120 manufacturing companies listed on BEJ 2004 as sample, this study used eight financial ratios (QR, TATO, CLTA, LDTA, GPM, ROE, PBV, and EPS). Those companies were divided into three size categories (small, medium and big) based on total assets. The result shows that PBV and EPS have significant influence on all models.

Sparta and Februwaty (2005) studied the affect of ROE, EPS, and CFO on stock return of manufacturing industry in BEJ using data of 32 manufacturing companies during 1999-2002. The result shows that only ROE that significantly influences stock return $(\alpha=5 \%)$ while EPS and CFO have insignificant negative effect on stock return.

Mais (2005) performed research on effect of financial ratios, including NPM, ROA, ROE, DER, and EPS, on stock price of companies listed on Jakarta Islamic Index in 2004. The outcome of this research explains that statistically all variables except DER are significant and have positive impact on stock price.

Kennedy (2005) analyzed the effect of ROA, ROE, EPS, Profit Margin, Assets Turnover, DTA, and DER on stock return using samples of stocks from LQ 45 index in BEJ during period 2001-2002. This research finds out that TATO, ROA, EPS, and DER have positive effect, while ROE and DTA have negative effect, on stock return. However, all variables are statistically insignificant in influencing stock return.

Roswati (2007) studied the effect of CR, TATO, DER, ROE, EPS, and PBV on stock price of manufacturing industry with five sub-industries including retail, food and beverages, tobacco, automotive, and pharmacy. The result shows that the significant financial ratios in retail industry are ROE, EPS, and PBV; In food and beverages industry are EPS and PBV; In tobacco industry are CR, TATO, DER, EPS, and PBV; In automotive industry are DER, ROE, EPS, and PBV; while in pharmacy industry are CR, EPS, and PBV. In overall five industries, the influential financial ratios are TATO, DER $<$ EPS, and PBV. Furthermore, this research shows that the variety of average stock prices can still be explained properly by financial ratios during 1-3 month period after the issuance of annual financial report.

Hamzah (2007) analyzed the correlation between financial ratios, including liquidity ratio (Current ratio), profitability ratio (Return on Investment), activity ratio (Total Assets Turnover), and solvability ratio (Debt to equity), and both capital gain (loss) and dividend in 135 manufacturing companies listed on Jakarta Stock Exchange.

This research discovers that all ratios have positive correlation with capital gain (loss). However, only Current ratio which is statistically significant $(\alpha=5 \%)$. Furthermore, for correlation with dividend yield, only Total 
assets turnover that is proved significant $(\alpha=10 \%)$.

A research on PBV ratio was conducted by Utama and Sentosa (1998) on 128 companies listed on Jakarta Stock Exchange in 1995. This research proves that PBV ratio can be used in setting investment strategy because by using PBV ratio, investor can predict which stocks will be undervalued and overvalued so they can gain significant return. Moreover, this research also discussed fundamental factors that affect PBV which are comprised of ROE, growth prospect, risk level, and dividend policy. The result confirmed that only ROE which has positive correlation with PBV consistently and significantly.

Some researchers have been studied about the effect of cash flow information. Manurung (1998) analyzed the effect of cash flow on stock return by using data from 40 firms listed on Jakarta Stock Exchange in the year 1994 and 1995. It was concluded that the correlation between cash flow, from operating, investing and financing activities, and stock return is weak, but becoming stronger each year. The correlation with cash flow from operating activities is positive but statistically insignificant for both 1994 and 1995 period. Moreover, the correlation with cash flow from investing and financing activities is positive in 1994 and negative in 1995, and also statistically insignificant for both years.

Another research on cash flow was conducted by Daniati and Suhairi (2006) with automotive and textile companies listed on Jakarta Stock Exchange in 1999-2004 as samples. They analyzed whether the cash flow information (operating, investing, and financing), gross profit, and company size affect firm's stock return significantly. The result proves that cash flow from investing activities, gross profit, and company size significantly correlate with stock return, while cash flow from operating activities does not affect the return significantly. (see Appendix 1)

\section{Methodology}

The diversity of research results on the correlation between stock return and financial ratios stimulates further research. This paper will discuss that correlation using the data from Jakarta Stock Exchange. The hypothesis that will be used is:

$\mathrm{H}_{1}$ : Net profit margin, return on equity, current ratio, debt to equity, total asset turnover, price to book value, cash flow from operating activities, and company size, each of them has significant correlation with market adjusted return dan abnormal return.

The regression model tested in this research and the description for each variable are as follow (Table 1):

\subsection{1a-1e model}

$$
\mathrm{RET}=\beta_{0}+\beta_{1} \mathrm{NPM}+\beta_{2} \mathrm{ROE}+\beta_{3} \mathrm{CR}+\beta_{4} \mathrm{DER}+\beta_{5} \mathrm{TATO}+\beta_{6} \mathrm{PBV}+\beta_{7} \mathrm{CFO} / \mathrm{Sales}+\beta_{8} \mathrm{LogTA}
$$

The dependent variables consist of two return variables, cumulative market adjusted return andcumulative abnormal return.

(1) Market adjusted return, that is the stock return deducted by market return (composite stock price index)

$$
\text { Cumulative market adjusted return } n_{i}=\sum_{t=0}^{n} R i-R m
$$

Where: $\quad R i=\frac{\left(R_{t}-R_{t-1}\right)+D_{t}}{R_{t-1}}, R m=\frac{I H S G_{t}-I H S G_{t-1}}{I H S G_{t-1}}$

(2) Abnormal return, that is the stock return deducted by expected return of the stock. 


$$
\text { Cumulative abnormal return } n_{i}=\sum_{t=0}^{n} R i-E(R i)
$$

The expected return is derived from market model where $E\left(R_{i}\right)=\alpha_{i}+\beta_{i} R_{m}$.

Table 1 Variables description

\begin{tabular}{|l|l|l|l|}
\hline \multicolumn{1}{|c|}{ Category } & \multicolumn{1}{c|}{ Symbol } & \multicolumn{1}{c|}{ Description } & Dependent \\
\hline Return & MKTADJRET & Cumulative market adjusted return & Dependent \\
\hline Return & ABNRET & Cumulative abnormal return & + \\
\hline Profitability & NPM & Net profit margin & + \\
\hline Profitability & ROE & Return on equity & + \\
\hline Liquidty & CR & Current ratio & + \\
\hline Leverage & DER & Debt to equity ratio & + \\
\hline Turnover & TATO & Total asset turnover & + \\
\hline Market ratio & PBV & Price to book value & + \\
\hline Size & TA & Total asset & + \\
\hline Cashflow & CFO/Sales & Cashflow from operation/Sales & + \\
\hline
\end{tabular}

Notes: RET $=$ uses two measurements: Cumulative market adjusted return and Cumulative abnormal return; NPM $=$ Net profit margin; $\mathrm{ROE}=$ Return on equity; $\mathrm{CR}=$ Current ratio; $\mathrm{DER}=$ Debt to equity ratio; $\mathrm{TATO}=$ Total asset turnover; $\mathrm{PBV}=\mathrm{Price}$ to book value; $\mathrm{CFO} /$ Sales $=$ Cashflow from operation/Sales; $\log \mathrm{TA}=\log$ (Total assets).

\subsection{Research sample}

This research used secondary data from financial statements (both interim and annual report), including income statement, balance sheet, and cash flow statement, issued by manufacturing companies listed on stock exchange. The data is obtained from Indonesian Capital Market DirectoryJSX Statistics, and Real Time Investor ${ }^{1}$.

This research also used weekly stock price from each firm and composite stock price index derived from Real Time Investor and Yahoo Finance. Moreover, other sources such as text book, newspapers, and journals are also utilized to review the theoretical framework from previous researches.

The sample in this research is manufacturing firms listed on BEI which are selected by purposive sampling. In choosing the sample, there were pre-determined criteria as follow:

(1) The firm has published its complete financial statements for 5 year period from 2002 to 2006.

(2) The firm's fiscal year-end is December.

(3) The firm does not have negative equity.

(4) The firm's stock has been actively traded during 2001-2006. It is determined by reviewing stock trading day every month. Transaction must take place at least in one day every month during 2001-2006.

The purposive sampling with the predetermined criteria above resulted in 39 firms as sample. The actively traded criterion was set to limit the sample from manufacturing companies with small stock price movement. Moreover, it was also set to concentrate the distribution of stock data so the parameter generated will be relatively efficient and has smaller variants (Daniati \& Suhairi, 2006).

The stock data used in this research is weekly stock data adjusted with stock split and dividend. The weekly data is an ideal alternative because it can generate a large number of observations as well as minimize the bias

\footnotetext{
${ }^{1}$ Real Time Investor provides real time financial data. PT RTI Infokom was selected by BEI to distribute data on real time basis to all BEI members. The data can be accessed on www.rti.co.id.
} 
from daily data (Lo \& MacKinlay, 1988).

After choosing dependent and independent variables, the next step is processing the data to get the appropriate model. To answer the problem in this study, statistical analysis is applied through multiple linear regression by using all independent variables to affect dependent variables in all quarterly data. For sensitivity analysis, regression analysis on all data model for each quarter will be performed.

\section{Results}

Descriptive statistics of each variable in this research is shown in Table 2. It can be seen from descriptive statistics that abnormal and market adjusted return of the firms were fluctuated from one quarter to another. The cumulative return in the fourth quarter is not always higher than the return in the next quarter.

Table 2 Descriptive statistics

\begin{tabular}{|c|c|c|c|c|c|c|c|c|c|c|}
\hline \multicolumn{9}{|c|}{$2002-2006$} & \multirow{2}{*}{\multicolumn{2}{|c|}{$\begin{array}{l}\text { 2002-2006 } \\
\text { All quarters }\end{array}$}} \\
\hline \multirow[b]{2}{*}{ Variable } & \multicolumn{2}{|c|}{ Q1 } & \multicolumn{2}{|c|}{ Q2 } & \multicolumn{2}{|c|}{ Q3 } & \multicolumn{2}{|c|}{ Q4 } & & \\
\hline & Mean & $\begin{array}{l}\text { Std. } \\
\text { Dev. }\end{array}$ & Mean & $\begin{array}{l}\text { Std. } \\
\text { Dev. }\end{array}$ & Mean & $\begin{array}{l}\text { Std. } \\
\text { Dev. }\end{array}$ & Mean & Std. Dev. & Mean & Std. Dev. \\
\hline NPM & 0.088 & 0.095 & 0.083 & 0.090 & 0.080 & 0.078 & 0.067 & 0.083 & 0.080 & 0.087 \\
\hline ROE & 0.050 & 0.060 & 0.093 & 0.113 & 0.133 & 0.132 & 0.120 & 0.370 & 0.099 & 0.208 \\
\hline $\mathrm{CR}$ & 2.370 & 1.475 & 2.197 & 1.331 & 2.299 & 1.520 & 2.370 & 1.652 & 2.309 & 1.498 \\
\hline DER & 1.365 & 1.241 & 1.402 & 1.197 & 1.343 & 1.150 & 1.343 & 1.151 & 1.363 & 1.183 \\
\hline TATO & 0.290 & 0.143 & 0.573 & 0.276 & 0.865 & 0.408 & 1.173 & 0.578 & 0.725 & 0.507 \\
\hline PBV & 1.698 & 1.933 & 1.840 & 2.254 & 1.697 & 1.999 & 1.905 & 2.527 & 1.785 & 2.188 \\
\hline CFO/SALES & 0.079 & 0.164 & 0.095 & 0.148 & 0.099 & 0.136 & 0.108 & 0.121 & 0.095 & 0.143 \\
\hline LOG (TA) & 9.219 & 0.675 & 9.233 & 0.680 & 9.241 & 0.685 & 9.243 & 0.689 & 9.234 & 0.681 \\
\hline MKTADJRET & 0.015 & 0.178 & 0.019 & 0.258 & 0.002 & 0.307 & -0.038 & 0.354 & -0.001 & 0.282 \\
\hline ABNRET & 0.024 & 0.181 & 0.032 & 0.268 & 0.020 & 0.329 & -0.008 & 0.388 & 0.017 & 0.301 \\
\hline $\mathrm{N}$ & \multicolumn{2}{|c|}{195} & \multicolumn{2}{|c|}{195} & \multicolumn{2}{|c|}{195} & \multicolumn{2}{|c|}{195} & \multicolumn{2}{|c|}{780} \\
\hline
\end{tabular}

Before running the regression, a test was performed on the classic assumption of these models. All models met the classic assumption and necessary treatments were given in the case of assumption violation.

The result of multiple regression is shown in Table 3. Both market adjusted return model and abnormal return model have significant F statistic with F-Stats probability 0.000 . This result suggests that with significance level of $95 \%$, the simultaneously tested independent variables have significant effect on dependent variable (market adjusted return). The value of $\mathrm{R}^{2}$ is $38.38 \%$ for market adjusted return and $37.94 \%$ for abnormal return which suggests that both dependent variables have consistent result. The $\mathrm{R}^{2}$ value shows that the level of stock return is not affected by independent variables tested in this research, but it is influenced more by other factors.

The result of regression on market adjusted return suggests that NPM, ROE, DER, and PBV have positive effect. In contrast, CR, TATO, $\log (\mathrm{TA})$, and CFO/Sales have negative correlation, which is not align to the hypothesis. Moreover, the result of regression on cumulative abnormal return shows that all variables, except TATO and $\log$ (TA), have negative correlation.

As evidenced by Table 3, NPM (Net profit margin) has significant positive influence on market return, which supports the result of research performed by Mais (2005). This indicates that the higher the firm's NPM, the higher market adjusted return and abnormal return that can be resulted by firm's stock, because a higher NPM 
means higher profit obtained from every dollar revenue earned by the firm.

Table 3 The result of regression for market adjusted return and abnormal return with financial ratios

\begin{tabular}{|c|c|c|c|c|}
\hline \multirow{2}{*}{ Variable } & \multicolumn{2}{|c|}{ Market adjusted return } & \multicolumn{2}{|c|}{ ABNRET } \\
\hline & Coef. & Prob. & Coef. & Prob. \\
\hline $\mathrm{C}$ & 0.30595 & 0.26970 & 0.74082 & $0.01030^{*}$ \\
\hline NPM? & 0.48739 & $0.00380 *$ & 0.43207 & $0.02140 *$ \\
\hline ROE? & 0.14062 & $0.06190 * *$ & 0.13709 & $0.03360 *$ \\
\hline CR? & -0.00260 & 0.75620 & 0.01121 & 0.22380 \\
\hline DER? & 0.02106 & 0.16430 & 0.00797 & 0.61330 \\
\hline TATO? & -0.05870 & $0.00570 *$ & -0.04371 & $0.05170 * *$ \\
\hline PBV? & 0.03920 & $0.00010^{*}$ & 0.04438 & $0.00000^{*}$ \\
\hline LOGTA? & -0.04434 & 0.14730 & -0.09291 & $0.00350 *$ \\
\hline CFOSALES? & -0.00412 & 0.96010 & 0.01513 & 0.85630 \\
\hline $\mathrm{N}$ & \multicolumn{2}{|c|}{780} & \multicolumn{2}{|c|}{780} \\
\hline R-squared & \multicolumn{2}{|c|}{0.39101} & \multicolumn{2}{|c|}{0.38661} \\
\hline Adjusted $\mathrm{R}^{2}$ & \multicolumn{2}{|c|}{0.38389} & \multicolumn{2}{|c|}{0.37943} \\
\hline F-statistic & \multicolumn{2}{|c|}{54.86170} & \multicolumn{2}{|c|}{53.85314} \\
\hline Prob(F-statistic) & \multicolumn{2}{|c|}{$0.00000 *$} & \multicolumn{2}{|c|}{$0.00000^{*}$} \\
\hline
\end{tabular}

$\mathrm{NI} /$ Total equity; $\mathrm{CR}=$ Current asset - Current liability; DER $=$ Total debt/Total equity; TATO $=$ Sales/Total asset; PBV $=$ Stock price/Book value equity.

Another variable, ROE (Return on equity), has significant positive correlation with return. A higher ROE shows that the firm can earn higher return on shareholder's equity. A higher ROE also indicates a higher efficiency in spending money invested by shareholder to earn profit growth. Therefore, it can be concluded that investor will pay attention on NPM and ROE. Purnomo (1997), Mais (2005), and Sparta and Februaty (2005) also argue that ROE has positive correlation with stock price.

Investors/shareholders consider current earnings, future earnings, and earnings stability are important, thus they focus their analysis on firm's profitability. They concern about financial condition which will affect firm's ability to pay dividend and avoid bankruptcy (Horne, 2002).

Liquidity ratio in both market adjusted return and abnormal return has insignificant effect on stock return. Even in market adjusted return model it has negative correlation.

The debt to equity ratio (DER) has positive correlation with stock return but not statistically significant. This positive correlation supports the research result by Purnomo (1998), Kennedy (2003), and Hamzah (2007). DER represents firm's capital structure. A high DER suggests that the firm uses debt financing aggressively. The fund can be used to support long term growth for the firm so it can earn profit. This suggests that the firm's debt level has not yet reached the level of financial distress.

Another variable, total assets turnover (TATO), has negative correlation with return. This contrasts the theory which states that TATO should have positive impact on market adjusted return and abnormal return. It is also contrast with the result of research performed by Kennedy (2003) and Roswati (2007). TATO reflects efficiency in assets management to earn revenue from operating activities, thus a higher TATO is a benefit for the firm and can give positive effect on stock return. The result of negative correlation of TATO on return might be caused by big 
firms' domination on high stock return, whereas big firms usually cannot increase their TATO easily. Another factor that caused negative correlation is that stock return is also affected by non operating profit which is not gained from sales.

The market ratio reflected by PBV (price to book value) also has positive impact on return, which supports Manao and Nur (2001). A low PBV can be an outcome of fundamental problem within the firm.

However, it does not agree with the research result from Fama \& French (1992), and Utama \& Santosa (1998) which proves that PBV has negative effect on stock return. This negative correlation can be rationalized by the value of PBV itself, that a very high PBV can cause overvalue on stock and thus the price will tend to decrease to reach the intrinsic value. Therefore, the stock return is low.

The company size which is indicated by total assets also correlates positively with return. This supports the study from Johnson and Soenen (2003). This correlation can be explained by some factors such as risk diversification, dominant market position, and a better access to capital market.

The last variable, $\mathrm{CFO} / \mathrm{Sales}$, has positive but insignificant correlation with both independent variables. A higher cash flow from operating activities will give positive impact on market adjusted return and abnormal return. This positive correlation is also concluded by Manurung (1998).

The sensitivity analysis with quarterly data did not provide a good result. This may be caused by the minimum amount of data. Even the result of regression on first quarter generated insignificant $F$ statistic which means the model cannot be used for prediction. There are fewer independent variables with significant effect on stock return; only about one or two variables, and the results were not consistent between one model and the others. The second quarter model has the highest $\mathrm{R}^{2}$, that is $13.48 \%$ and $10.45 \%$ (see Appendix 2 and Appendix 3), compared to the other models, even with fourth quarter and annual data.

\section{Conclusion and limitation}

Based on regression result, it can be concluded that financial ratios, firm size, and cash flow from operating activities altogether affect market adjusted return and abnormal return. The return variability is best explained by second quarter report.

The variables which are consistently significant on adjusted return and abnormal return are profitability ratios (NPM and ROE), TATO, and market value ratio (PBV). It shows that from investors' point of view financial ratios are useful in making decision on investment.

This research also exposes that the movement of stock price is affected much by factors other than firm's financial performance. From all models used in this research, the highest $\mathrm{R}^{2}$ is only $39.1 \%$. It suggests that there is other information other than internal fundamental factors that also affect the movement of firm's stock price. In certain periods, the changes in stock price do not reflect the firm's financial performance. Macro economic condition, political situation, government industrial policy, and technical aspects within firms are factors other than financial performance that can affect the changes in stock price (Purnomo, 1998). Hadi and Azmi (2005) also argued that other factors such as interest rate, inflation rate, and exchange rate can influence changes in stock return significantly.

Considering the limitation in numbers of firms and observed period, it is suggested to increase the sample in both number of firms and observation period for the next research. To reduce the variability of dependent variable (stock return), researchers can classify the firms based on certain criteria, such as company size (total assets or 
market capitalization) or risk level (for example firm's leverage). Furthermore, other macro level variables which can influence stock return such as interest rate, economic growth (GDP), and inflation can be used to expand the next research.

\section{References:}

Abarbanell, Jeffery S. \& Bushee, Brian J.. (1998, January). Abnormal returns to a fundamental analysis strategy. The Accounting Review, 73(1), 19-45.

Baker, Richard E., Lembke, Valdean C., King, Thomas E. \& Jeffery, Chinthia G.. (2008). Advanced financial accounting (7th ed.). USA: McGraw Hill.

Brown, Philip \& Niederhoffer, Victor. (1968, October). The predictive content of quarterly earnings. The Journal of Business, 41(4), 488-497.

Daniati, Nina; Suhairi. (2006, August, 23-26). Pengaruh kandungan informasi komponen laporan arus kas, laba kotor, dan size perusahaan terhadap expected return saham (survey pada industri textile dan automotive yang terdaftar di BEJ). Padang: Simposium Nasional Akuntansi 9.

Dhankani, Dinesy. (2005). Fundamental analysis and stock returns India 2000-2005. The Business Review, Cambridge, 4(2), 218.

Firth, Michael. (1976, June). The impact of earnings announcements on the share price behavior of similar type firms. The Economic Journal, 86(342), 296-306.

Gujarati, Damodar N.. (2003). Basic econometrics (4th ed.). USA: Mcgraw Hill.

Höbarth, Mag Lukas L.. (2006). Modeling the relationship between financial indicators and company performance-An empirical study for us listed companies. France: Dissertation Vienna University of Economics And Business Administration.

Johnson, Robert \& Soenen, Luc. (2003). Indicator of successful companies. European Management Journal, 21(3), $364-369$.

Fama, Eugene F. \& French, Kenneth R.. (1995, March). Size and book-to-market factors in earnings and returns. The Journal of Finance, 50(1), 131-155.

Hadi, Subakti S. \& Azmi, Taufik. (2005, January-March). Analisis faktor-faktor yang mempengaruhi tingkat pengembalian saham sektor perdagangan pada bursa efek jakarta. Jurnal Ekonomi STEI, 14(1), 28.

Husnan, Suad \& Hermanto, Suwardi B.. (1998, May). CAPM \& Strategi portofolio kajian kondisi pasar di BEJ 1997. Usahawan, 27(5).

Jones, Charles P.. (2004). Investment analysis and management (9th ed.). USA: John Wiley \& Sons.

Kennedy, Posma Sariguna Johnson. (2003). Analisis pengaruh ROA, ROE, EPS, profit margin, asset turnover, leverage, DER terhadap return saham: Studi pada saham-saham yang termasuk dalam lq-45 di bursa efek jakarta. Thesis in Pasca Sarjana Ilmu Manajemen FEUI.

Lev, Thigarajan. (1993, Autumn). Fundamental information analysis. Journal of Accounting Research, 31(2), 190-215.

Lewellen, Jonathan. (2004). Predicting returns with financial ratios. Journal of Financial Economics, 74, 209-235.

Machfoedz, Mas'ud. (1999). Profil kinerja finansial perusahaan-perusahaan yang go-public di pasar modal asean. Jurnal Ekonomi dan Bisnis Indonesia, 14(3), 56-72.

Mais, Rimi Gusliana. (2005, July-September). Pengaruh rasio-rasio keuangan utama perusahaan terhadap harga saham perusahaan yang terdaftar di jakarta islamic index tahun 2004. Jurnal Ekonomi STEI, 14(3), 30.

Manao, Hekinus \& Nur, Deswin. (2001). Asosiasi rasio keuangan dengan return saham: pertimbangan ukuran perusahaan serta pengaruh krisis ekonomi di indonesia. Simposium Nasional Akuntansi IV.

Manurung, Adler Haymas. (1998). Analisis arus kas terhadap tingkat pengembangan saham di bursa efek jakarta. Usahawan, 5, 11-18.

Marpaung, Elysabet Indrawati. (2003, November). Perubahan dividend yield dan perubahan price earning ratio terhadap perubahan harga saham. Journal Ilmiah Akuntansi, 2(1).

May, Robert G.. (1971). The Influence of quarterly earnings announcements on investor decisions as reflected in common stock price changes. Journal of Accounting Research, 9, 119-163.

Meythi. (2006, August, 23-26). Pengaruh arus kas operasi terhadap harga saham dengan persistensi laba sebagai variabel intervening. Padang: Simposium Nasional Akuntansi.

Nachrowi, Nacrowi D. \& Usman, Haridius. (2006). Pendekatan populer dan praktis ekonometrika untuk analisis ekonomi dan keuangan. Lembaga Penerbit Fakultas Ekonomi UI.

O'connor, Melvin. (1973, April). On the usefulness of financial ratios to investors in common stock. The Accounting Review, 48(2), 
339-352.

Ohlson, James A.. (1980, Spring). Financial ratios and the probabilistic prediction of bankruptcy. Journal of Accounting Research, 18(1), 109-131.

Palepu, Healy, Bernard. (2004). Business analysis and valuation using financial statements (3rd ed.). USA: Thomson-Southwestern.

Purnomo, Yogo. (1998, December). Keterkatitan kinerja keuangan dengan harga saham. Usawahan, 27(12).

Prasetya, Teguh. (2000). Analisa rasio keuangan dan nilai kapitalitsasi pasar sebagai perdiksi harga saham di bej pada periode bullish dan bearish. Simposium Nasional Akuntansi 3.

Pyndick, Robert S. \& Rubinfield, Daniel L.. (1998). Econometric models and economic forecasts (4th ed.). USA: Mcgraw Hill.

Rahardja, Maurus Heri Pudji. (2005). Prediksi Return Saham dengan Rasio Keuangan di BEJ Tahun 1999-2002. Thesis in Pascasarjana FEUI.

Reilly, Frank K., Morgenson, David L. \& West, Marilyn. (1972). The predictive ability of alternative parts of interim financial statements. Journal of Accounting Research, 10, 105-124.

Restraningtyas, Anindhia. (2007). Analysis of accrual, cashflow, net income, dividend and price to book value toward companeies abnormal return in manufacturing sector of bej (2002-2005). Thesis in FEUI.

Sparta, Februaty. (2005, January). Pengaruh ROE, EPS, OCF terhadap harga saham industri manufacturing di bursa efek jakarta. Jurnal Akuntansi, 9(1).

Susanto, San \& Ekawati, Erni. (2006, August, 23-26). Relevansi nilai informasi laba dan aliran kas terhadap harga saham dalam kaitannya dengan siklus hidup perusahaan. Padang: Simposium Nasional Akuntansi 9.

Taylor, Robert G.. (1965, January). A look at published interim reports. The Accounting Review, 40(1), 89-96.

Utama, Siddharta \& Santosa, Anto Yulianto Budi. (1998, January). Kaitan Antara rasio price/Book value dan imbal hasil saham pada bursa efek jakarta. Jurnal Riset Akuntansi Indonesia, 1(1), 127-140.

Warfield, Terry D. \& Wild, John J.. (1992, Qctober). Accounting recognition and the relevance of earnings as an explanatory variable for returns. The Accounting Review, 67(4), 821-842.

Weygant, Jerry J. \& Bollom, William J.. (1972, January). An examination of some interim reporting theories for a seasonal business. The Accounting Review, 47(1), 75-84.

(Edited by Annie and Chris)

Appendix 1 Previous researches

\begin{tabular}{|c|c|c|c|}
\hline Research & $\begin{array}{l}\text { Independen } \\
\text { t variables }\end{array}$ & Dependent variables & Significant variables \\
\hline $\begin{array}{l}\text { O'Connor } \\
(1973)\end{array}$ & $\begin{array}{l}\text { Stock } \\
\text { returns }\end{array}$ & 33 financial ratios & $\begin{array}{l}\text { Total liabilities/Net worth, } \\
\text { income for common stock to net } \\
\text { worth, cash flows to number of } \\
\text { common stocks, current } \\
\text { liabilities to inventory dan } \\
\text { earnings per share to stock price }\end{array}$ \\
\hline $\begin{array}{l}\text { Lev, } \\
\text { Thiagarajan } \\
(1993)\end{array}$ & $\begin{array}{l}\text { Abnormal } \\
\text { stock return }\end{array}$ & $\begin{array}{l}\text { Changes in inventory, accounts receivable, capital expenditure, } \\
\text { R\&D, gross margin, sales \& administrative expense, provision } \\
\text { for doubtful receivable, effective tax, order backlog, labor force, } \\
\text { LIFO earnings, audit qualification. }\end{array}$ & $\begin{array}{l}\text { Changes in inventory, } \\
\text { receivable, capital expenditure, } \\
\text { gross margin, sales \& } \\
\text { administrative expense, order } \\
\text { backlog }\end{array}$ \\
\hline $\begin{array}{l}\text { Abarbanel, } \\
\text { Bushee } \\
\text { (1998) }\end{array}$ & $\begin{array}{l}\text { Abnormal } \\
\text { stock return }\end{array}$ & $\begin{array}{l}\text { Changes in inventory, accounts receivable, gross margins, } \\
\text { selling expenses, capital expenditures, effective tax rates, } \\
\text { inventory methods, audit qualifications, and labor force sales } \\
\text { productivity }\end{array}$ & $\begin{array}{l}\text { Changes in inventory, gross } \\
\text { margin, selling expenses }\end{array}$ \\
\hline $\begin{array}{l}\text { Hobarth } \\
\text { (2006) }\end{array}$ & $\begin{array}{l}\text { Stocks } \\
\text { return } \\
\text { (Market } \\
\text { value) }\end{array}$ & $\begin{array}{l}\text { Book to market ratio, size, sustainable growth rate, return on } \\
\text { asset, capital structure, cash conversion cycle, research and } \\
\text { development expenditure, advertising expenditure, capital } \\
\text { expenditure, auditor's opinion, p-ratio, quick ratio, sales } \\
\text { percentage change, EBIT margin, long term credit rating, short } \\
\text { term credit rating, common stock rating) }\end{array}$ & $\begin{array}{l}\text { Low book to market ratio, } \\
\text { efficient working capital } \\
\text { management, higher equity, low } \\
\text { stock rating, low level of assets, } \\
\text { high EBIT margin, high } \\
\text { profitability }\end{array}$ \\
\hline $\begin{array}{l}\text { Anggraini, } \\
\text { Setiawati, } \\
\text { Desembriar } \\
\text { to }(2004)\end{array}$ & $\begin{array}{l}\text { Abnormal } \\
\text { Stock } \\
\text { return }\end{array}$ & $\begin{array}{l}\text { Inventory, accounts receivable, gross profit, marketing and } \\
\text { administrative expense, allowance for bad debt/sales, effective } \\
\text { tax rate, audit qualification. }\end{array}$ & $\begin{array}{l}\text { During crisis period: gross profit } \\
\text { During non-crisis period: } \\
\text { inventory, financial statements, } \\
\text { and audit qualification }\end{array}$ \\
\hline
\end{tabular}

(to be continued) 
The effect of financial ratios, firm size, and cash flow from operating activities in the interim report to the stock return

\begin{tabular}{|c|c|c|c|}
\hline $\begin{array}{l}\text { Manao, Nur } \\
(2001)\end{array}$ & $\begin{array}{l}\text { Stock } \\
\text { return }\end{array}$ & QR, TATO, CLTA, LDTA, GPM, ROE, PBV, EPS & PBV, EPS \\
\hline $\begin{array}{l}\text { Prasetya } \\
(2000)\end{array}$ & $\begin{array}{l}\text { Stock } \\
\text { return }\end{array}$ & $\begin{array}{l}\text { Earnings per price (1/PER), Book value per price (1/PBV), } \\
\text { Debt to total asset (DTA), Return on equity (ROE), Net profit } \\
\text { Margin (NPM), Operating profit margin (OPM). }\end{array}$ & $\begin{array}{l}\text { Bullish period: EPP, BPP, DTA, } \\
\text { OPM, Log MCap. Bearish: BPP, } \\
\text { DTA, ROE. }\end{array}$ \\
\hline $\begin{array}{l}\text { Purnomo } \\
(1998)\end{array}$ & Stock price & EPS, PER, DER, ROE, DPS & D \\
\hline $\begin{array}{l}\text { Sparta, } \\
\text { Februwaty } \\
(2005)\end{array}$ & $\begin{array}{l}\text { Stock } \\
\text { return }\end{array}$ & ROE, EPS and CFO & ROE \\
\hline $\begin{array}{l}\text { Mais } \\
(2005)\end{array}$ & Stock price & NPM, ROA, ROE, DER, EPS & NPM, ROA, ROE, DER, EPS \\
\hline $\begin{array}{l}\text { Kennedy } \\
(2003)\end{array}$ & $\begin{array}{l}\text { Stock } \\
\text { return }\end{array}$ & ROA, ROE, EPS, Profit Margin, Asset Turnover, DTA, DER & - \\
\hline $\begin{array}{l}\text { Roswati } \\
\text { (2007) }\end{array}$ & Stock price & CR, TATO, DER, ROE, EPS, PBV & TATO, DER, EPS, PBV \\
\hline $\begin{array}{l}\text { Hamzah } \\
(2007)\end{array}$ & $\begin{array}{l}\text { Stock } \\
\text { return, } \\
\text { dividend }\end{array}$ & CR, ROI, TATO, DER & Return: CR, dividend: TATO \\
\hline $\begin{array}{l}\text { Utama, } \\
\text { Sentosa } \\
(1998)\end{array}$ & $\begin{array}{l}\text { Stock } \\
\text { return, } \\
\text { PBV }\end{array}$ & Return: PBV; PBV: ROE, growth, beta, dividend & Return: PBV; PBV: ROE \\
\hline $\begin{array}{l}\text { Daniati, } \\
\text { Suhairi } \\
(2006)\end{array}$ & $\begin{array}{l}\text { Stock } \\
\text { return }\end{array}$ & $\begin{array}{l}\text { Cash flow from operating, investing, and financing actvities, } \\
\text { gross profit, company size. }\end{array}$ & $\begin{array}{l}\text { Cash flow from investing } \\
\text { activities, gross profit, and } \\
\text { company size }\end{array}$ \\
\hline $\begin{array}{l}\text { Manurung } \\
(1998)\end{array}$ & $\begin{array}{l}\text { Stock } \\
\text { return }\end{array}$ & Cash flow from operating, investing, and financing actvities. & 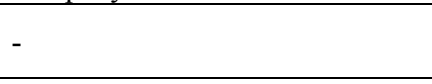 \\
\hline $\begin{array}{l}\text { Meythi } \\
(2006)\end{array}$ & Stock price & Cash flow from operating activities. & 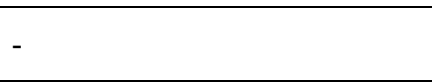 \\
\hline $\begin{array}{l}\text { Restraningt } \\
\text {-yas (2007) }\end{array}$ & Return & Accrual, cash flow, net income, dividend, PBV & $\begin{array}{l}\text { Accrual, cash flow, net income, } \\
\text { dividend, PBV }\end{array}$ \\
\hline
\end{tabular}

Appendix 2 Regression result on each quarter with market adjusted return as independent variable (1a-1d model)

\begin{tabular}{|c|c|c|c|c|c|c|c|c|}
\hline Model & \multicolumn{2}{|c|}{$1 \mathrm{a}$} & \multicolumn{2}{|c|}{$1 b$} & \multicolumn{2}{|c|}{$1 \mathrm{c}$} & \multicolumn{2}{|c|}{$1 d$} \\
\hline Quarter & \multicolumn{2}{|c|}{ Q1 } & \multicolumn{2}{|c|}{ Q2 } & \multicolumn{2}{|c|}{ Q3 } & \multicolumn{2}{|c|}{ Q4 } \\
\hline Variable & Coef. & Prob. & Coef. & Prob. & Coef. & Prob. & Coef. & Prob. \\
\hline $\mathrm{C}$ & 0.11163 & 0.63020 & -0.11810 & 0.70530 & 0.49082 & 0.26860 & -0.30050 & 0.48930 \\
\hline NPM? & 0.39873 & 0.14190 & 0.64944 & $0.08270 * *$ & 0.25728 & 0.63050 & 0.77593 & 0.12640 \\
\hline ROE? & -0.54336 & 0.46090 & 0.60714 & $0.05740 * *$ & 1.02546 & $0.00200 *$ & 0.10708 & 0.23400 \\
\hline $\mathrm{CR}$ ? & 0.00760 & 0.44490 & 0.00359 & 0.81330 & -0.01930 & 0.28750 & -0.00998 & 0.57100 \\
\hline DER? & 0.03835 & 0.10400 & 0.03009 & $0.07700 * *$ & 0.01732 & 0.37530 & 0.05471 & 0.03020 * \\
\hline TATO? & 0.06614 & 0.59780 & -0.01912 & 0.82380 & -0.13354 & 0.13360 & 0.03116 & 0.53070 \\
\hline PBV? & 0.01230 & 0.30520 & -0.00653 & 0.51480 & -0.01491 & 0.33250 & 0.00734 & 0.52430 \\
\hline LOGTA? & -0.02321 & 0.35310 & 0.00373 & 0.90700 & -0.05025 & 0.21680 & 0.00723 & 0.87440 \\
\hline CFOSALES? & -0.00341 & 0.96420 & -0.37108 & $0.00740 *$ & -0.20050 & 0.28050 & 0.28273 & 0.30660 \\
\hline $\mathrm{N}$ & \multicolumn{2}{|c|}{195} & \multicolumn{2}{|c|}{195} & \multicolumn{2}{|c|}{195} & \multicolumn{2}{|c|}{195} \\
\hline R-squared & \multicolumn{2}{|c|}{0.05293} & \multicolumn{2}{|c|}{0.17055} & \multicolumn{2}{|c|}{0.14846} & \multicolumn{2}{|c|}{0.12280} \\
\hline Adjusted R2 & \multicolumn{2}{|c|}{0.01219} & \multicolumn{2}{|c|}{0.13487} & \multicolumn{2}{|c|}{0.11184} & \multicolumn{2}{|c|}{0.08508} \\
\hline F-statistic & \multicolumn{2}{|c|}{1.29933} & \multicolumn{2}{|c|}{4.78057} & \multicolumn{2}{|c|}{4.05348} & \multicolumn{2}{|c|}{3.25491} \\
\hline Prob(F-statistic) & \multicolumn{2}{|c|}{0.24617} & \multicolumn{2}{|c|}{$0.00002 *$} & \multicolumn{2}{|c|}{$0.00018^{*}$} & \multicolumn{2}{|c|}{$0.00171^{*}$} \\
\hline
\end{tabular}

Notes: * Significant at $\alpha=5 \%$;* Significant at $\alpha=10 \%$; NPM $=$ NI/Sales; ROE $=$ NI/Total equity; CR = Current asset Current liability; DER $=$ Total debt/Total equity; TATO $=$ Sales/Total asset; $\mathrm{PBV}=$ Stock price/Book value equity. 
Appendix 3 Regression result for each quarter with abnormal return as independent variable (2a-2d model)

\begin{tabular}{|c|c|c|c|c|c|c|c|c|}
\hline Model & \multicolumn{2}{|c|}{$2 \mathrm{a}$} & \multicolumn{2}{|c|}{$2 \mathrm{~b}$} & \multicolumn{2}{|c|}{$2 \mathrm{c}$} & \multicolumn{2}{|c|}{$2 d$} \\
\hline Quarter & \multicolumn{2}{|c|}{ Q1 } & \multicolumn{2}{|c|}{ Q2 } & \multicolumn{2}{|c|}{ Q3 } & \multicolumn{2}{|c|}{ Q4 } \\
\hline Variable & Coef. & Prob. & Coef. & Prob. & Coef. & Prob. & Coef. & Prob. \\
\hline $\mathrm{C}$ & 0.30656 & 0.19780 & 0.44291 & 0.17960 & 1.24540 & $0.00980^{*}$ & 0.76761 & 0.11350 \\
\hline NPM? & 0.56623 & $0.05020 * *$ & 0.89396 & $0.02390 *$ & 0.54717 & 0.32170 & 0.82359 & 0.14490 \\
\hline ROE? & -0.83059 & 0.26700 & 0.35489 & 0.29050 & 0.82340 & $0.01250 *$ & 0.13129 & 0.19000 \\
\hline CR? & 0.00882 & 0.35990 & 0.00214 & 0.89380 & -0.01794 & 0.33390 & 0.00373 & 0.84920 \\
\hline DER? & 0.03413 & 0.14050 & 0.02253 & 0.20820 & 0.01841 & 0.37370 & 0.05709 & $0.04200^{*}$ \\
\hline TATO? & 0.10690 & 0.40660 & -0.00319 & 0.97190 & -0.12818 & 0.20670 & 0.00636 & 0.90840 \\
\hline PBV? & 0.01520 & 0.19960 & 0.00199 & 0.85070 & -0.00138 & 0.93360 & 0.01836 & 0.15300 \\
\hline LOGTA? & -0.04488 & $0.07750 * *$ & -0.05697 & $0.09130 * *$ & -0.13357 & $0.00270 *$ & -0.10882 & $0.03370 *$ \\
\hline CFOSALES? & -0.01754 & 0.82300 & -0.32117 & $0.02730 *$ & -0.14915 & 0.47750 & 0.28885 & 0.34790 \\
\hline $\mathrm{N}$ & \multicolumn{2}{|c|}{195} & \multicolumn{2}{|c|}{195} & \multicolumn{2}{|c|}{195} & \multicolumn{2}{|c|}{195} \\
\hline R-squared & \multicolumn{2}{|c|}{0.06538} & \multicolumn{2}{|c|}{0.14141} & \multicolumn{2}{|c|}{0.13297} & \multicolumn{2}{|c|}{0.09377} \\
\hline Adjusted R2 & \multicolumn{2}{|c|}{0.02518} & \multicolumn{2}{|c|}{0.10448} & \multicolumn{2}{|c|}{0.09568} & \multicolumn{2}{|c|}{0.05479} \\
\hline F-statistic & \multicolumn{2}{|c|}{1.62646} & \multicolumn{2}{|c|}{3.82918} & \multicolumn{2}{|c|}{3.56572} & \multicolumn{2}{|c|}{2.40568} \\
\hline Prob(F-statistic) & \multicolumn{2}{|c|}{0.11974} & \multicolumn{2}{|c|}{$0.00034^{*}$} & \multicolumn{2}{|c|}{$0.00072 *$} & \multicolumn{2}{|c|}{$0.01712 *$} \\
\hline
\end{tabular}

Notes: * Significant at $\alpha=5 \%$; ** Significant at $\alpha=10 \%$; NPM $=$ NI/Sales; ROE $=$ NI/Total equity; CR = Current asset Current liability; DER $=$ Total debt/Total equity; TATO $=$ Sales/Total asset; PBV $=$ Stock price/Book value equity.

\section{(continued from Page 43)}

For the solution of the trade game between developing and developed countries, we design a two country model. By simulation of the model, the different strategies of a virtual developing country for the trade game are compared. Based on the analysis on the simulation results, we suggest two strategies. They are to advance the technical standard level and reduce the export subsidy.

\section{References:}

Calvin L. \& Krissoff B.. (1998). Technical Barriers to Trade: A case study of phytosanitary barriers and US-Japanese apple trade. Journal of Agricultural and Resource Economics, 23(2), 351-356.

JI Rui. (2008). Research survey on Technical Barriers to Trade. Commercial Economy, 2, 88-90. (in Chinese)

JIANG Jian-ye. (2002a). Analysis on problem of "soft barriers" when China joined WTO. Guangdong Economy, 11, 11-13. (in Chinese)

JIANG Jian-ye. (2002b). Strategy study for problem of "soft barriers". Guangdong Economy, 12, 22-24. (in Chinese)

JIANG Jian-ye. (2002c). Study on barrier economics. Guangdong Economy, 11, 6-7. (in Chinese)

Málaga J. E., Williams G. W. \& Fuller S. W.. (2001) US-Mexico fresh vegetable trade: The effects of trade liberalization and economic growth. Agricultural Economics, 26, 45-55.

Sarkar A.. (1989). A Keynesian model of North-South trade. Journal of Development Economics, 30, 179-188.

Suga N. (2005). International economies of scale and the gains from trade. Journal of Economics, 85(1), 73-97.

SUN Long-zhong \& XU Song. (2008). The impact of Technical Barriers to Trade to the export of China agricultural products and countermeasures. International Trade Problems, 2, 26-34. (in Chinese)

TANG Hai-bin \& WANG Ying. (2007). Intensity measure of Non-Tariff Barriers with application to South-Eastern Asia Union. Practice in Foreign Economic Relations and Trade, 7, 37-40. (in Chinese)

YANG Bo. (2007). The cause of Technical Barriers to Trade game and empirical study. World Economy Study, 10, 41-47. (in Chinese)

ZHOU Wei-min. (2005). How to effectively measure the Technical Barriers to Trade. Industrial Engineering and Management, 5, 64-67. (in Chinese)

ZHANG Hong-min \& GE Jia-li. (2002). Simulation of complexity for China's energy economy system. Journal of Systems Simulation, 14(11), 1443-1446. (in Chinese)

(Edited by Annie and Ann) 